\title{
Hydrological analysis of Freshwater Canal in Meerut District (U.P.) India
}

\author{
Madhu, Neera Singh and Archana Arya ${ }^{1}$ \\ Department of Zoology, Meerut College, Meerut. \\ ${ }^{1}$ Department of Basic Science, SVP University of Agriculture \& Technology, Meerut.
}

\begin{abstract}
The present study deals with physico-chemical characteristics of Mawana canal in Meerut District (U.P.), India. The physico-chemical parameters were studied during the period from Feb 2009 to Jan 2010. Various parameters like temperature, transparency, $\mathrm{pH}$, free $\mathrm{CO}_{2}$, total dissolve solids, calcium, magnesium, alkalinity, chloride and dissolved oxygen were analyzed from surface water of canal. The transparency was lowest during the monsoon months. The dissolve oxygen and free $\mathrm{CO}_{2}$ showed negative correlation. Alkalinity values ranged between 50.00 to $50.3 \mathrm{mg} / 1$ indicating moderate productive waters throughout the period. The phosphate phosphorous, silicate and calcium values were also find in medium productive range. A perusal of the foregoing reveals that the water quality of the Mawana Canal is moderate less productive and thus suitable for fish production and other purposes.
\end{abstract}

Key Words: Physico-chemical, Transparency, pH, Alkalinity, Parameters and correlation.

Paper Cited: Madhu, Singh, N. and Arya, A. (2016). Hydrological analysis of freshwater canal in Meerut District (U.P.) India. South Asian Journal of Food Technology and Environment, 2(1):334-337.

Received: 11/01/2016 Revised: 19/01/2016 Accepted: 07/02/2016

\section{Introduction}

Comprising 70 percent of earth's surface, water is undoubtedly one of the most precious natural resource that exists on our planet. Without this seemingly invaluable compound comprising of hydrogen and oxygen, life on earth would be non-existing. It is essential for everything on our planet to grow and prosper. It is because of this reason that all early civilizations started and grew on the banks of river. The present study deals with physicochemical characteristics of freshwater canal in Meerut District (U.P.), India and is aimed to analysis its hydrological status.

\section{Materials and Methods}

The present study was carried out on upper Ganga canal in Mawana town of District Meerut, located in plain of Western region in Uttar Pradesh. The canal is used for irrigation of farming. Two sampling stations (A and B) were selected for collecting samples. One of the station (A) was located before the Mawana Sugar Mills, the second sampling station selected (B) was situated approximately $10 \mathrm{~km}$ downstream. Samples were collected on monthly basis, for a period of one year from February 2009 to January 2010 for analysis and study of the different physico-chemical parameters. The analyses were carried out as per APHA (1985).

\section{Results and Discussion}

The range of various physicochemical parameter of canal water is presented in Table 1.

Temperature: The variation in temperature range from $16.5-26.8^{\circ} \mathrm{C}$ and $17.0-28^{0} \mathrm{C}$. The temperature was recorded lowest in the month of December both the stations and highest in the month July at station (A), Jun at station B. Temperature of water body is also important for the growth of organisms. The temperature of atmosphere at water plays important role in physico-chemical and physiological behaviour of the water body. According to Welch (1952), the temperature exerts profound direct or indirect influence on metabolic and 
physiological behaviour of aquatic ecosystem. During the present study the variation the water temperature were due to seasonal variations as well as due to pouring of sugar mill wastes.

Transparency: The variations in values of transparency range from $55-140 \mathrm{~cm}$ and 90 $130 \mathrm{~cm}$ at station (A) and station (B) respectively. The transparency was reported lowest and highest in the month of August and January respectively at both the stations. Transparency is a characteristic of water that various seasonally. During rainy season water of all body become turbid causing low transparency. Low values of transparency during season are mainly due to silt brought through rain water. According to Thirupathaih et al., (2012), gradually suspended particles are settled causing high transparency.

Hydrogen Ion Concentration (pH): The $\mathrm{pH}$ ranges from 6.6-7.5 at station (A) and 7.0-7.8 at station (B). The lowest values of $\mathrm{pH}$ are recorded in the month of May at station (A) and in the month of June at station (B); the highest values are observed in the month of December at both the stations. The alkaline $\mathrm{pH}$ is considered to be good for promoting high primary productivity. According to Fakayode
(2005), the $\mathrm{pH}$ of water body is very important in determination of water quality since it affects other chemical reactions such as solubility and metal toxicity.

Free Carbon Dioxide: The values of free carbon dioxide at the station (A) ranged from $0.1-0.9 \mathrm{mg} / 1$ and at (B) ranged from 0.1 $0.8 \mathrm{mg} / 1$. The lowest values of free carbon dioxide were recorded in the month of December, January at station (A) and station (B), highest values in the month of July at both stations. Free carbon dioxide in the water is by product of metabolism. Carbon dioxide is required for photosynthesis hence effects concentration of phytoplankton and its productivity. It was similar to trend noted in fresh water by Mohan et al., (2001).

Total Dissolved Solid (TDS): The total dissolved solid ranges from $55.0-78.0 \mathrm{mg} / \mathrm{l}$ at station (A) and $60.0-80.1 \mathrm{mg} / \mathrm{l}$ at station (B). The values of TDS lowest and highest in the month of February and July at both the stations respectively. In fresh water the total dissolved solids content varies from 10$500 \mathrm{mg} / 1$ (Sharma, 2000) and Mohan et al., (2001) have reported the TDS values ranging between $63 \mathrm{mg} / 1$ to $112.19 \mathrm{mg} / 1$ at two stations of Gaula River in the Kumaon region.

Table1: Physico-Chemical Characteristics of Mawana Canal at Station (A and B)

\begin{tabular}{|l|c|c|}
\hline Parameters & Station $\mathbf{A}$ & Station B \\
\hline Temperature $\left({ }^{0} \mathrm{C}\right)$ & $16.5-26.8$ & $17.0-28.0$ \\
\hline Transparency $(\mathrm{cm})$ & $55-140$ & $90-130$ \\
\hline Hydrogen ion concentration $\mathrm{pH}$ & $6.6-7.5$ & $7.0-7.8$ \\
\hline FreeCO ${ }_{2}(\mathrm{mg} / \mathrm{l})$ & $0.1-0.9$ & $0.1-0.8$ \\
\hline TDS $(\mathrm{mg} / \mathrm{l})$ & $55.0-78.0$ & $60.0-80.1$ \\
\hline Calcium $(\mathrm{mg} / \mathrm{l})$ & $24.0-24.9$ & $24.0-24.9$ \\
\hline Magnesium(mg/l) & $20.0-20.9$ & $20.4-21.1$ \\
\hline Chloride(mg/l) & $12.0-12.39$ & $12.0-12.54$ \\
\hline Dissolved Oxygen $(\mathrm{mg} / \mathrm{l})$ & $4.2-5.1$ & $4.2-5.0$ \\
\hline Alkalinity(mg/l) & $50.18-50.28$ & $50.18-50.30$ \\
\hline Phosphorous(mg/l) & $0.42-0.51$ & $0.40-0.51$ \\
\hline Silicates(mg/l) & $0.32-0.54$ & $0.38-0.49$ \\
\hline
\end{tabular}

Calcium: Calcium is another major component of natural water coming mainly from rocks seepage, drainage and wastes water. The range of values was calcium from $24.0-24.9 \mathrm{mg} / 1$ at both the stations. The values of calcium were lowest and highest in the month of July and January at both the stations.
Magnesium: The Magnesium ranges from 20.0-20.9 at station (A) and 20.4-21.1 mg/l at station (B). During present study at station (A) magnesium concentration increased in winter (December) and decreased (June) in summer. 
Similar trend was noted by Verma et al., (2011) and Patil et al., (2013). Magnesium is essential nutrient for plants and animals. It occurs in all kinds of waters in combination with bicarbonate. It has an important role in primary production, as it is a component of the chlorophyll and must be available for its proper development.

Chloride: The values of chloride at the station (A) ranged from $12.0-12.39 \mathrm{mg} / \mathrm{l}$ and at (B) it ranged from $12.0-12.54 \mathrm{mg} / \mathrm{l}$. The lowest values of chloride were recorded in the month of August at both the stations and highest values in the month of April and March respectively, at both the stations. Chloride is considered an important parameter in assessing the water quality. According to Banerjee (1967), chloride ions control the salinity of water and osmotic stress on biotic communities.

Dissolved Oxygen: The values of dissolved oxygen at the station (A) ranged from 4.2-5.1 $\mathrm{mg} / \mathrm{l}$ and (B) ranged from 4.2-5.0 mg/l. The lowest values of dissolved oxygen were recorded in the month of August at both the stations and highest values in the month of December and February respectively, at both the stations. The oxygen content of water body is important parameter in its quality assessment. Its presence is essential in aquatic ecosystem to keep the organism in balance. It also affects the solubility and availability of many hence affecting the productively of aquatic ecosystem (Wetzel, 1983).

Alkalinity: The values of alkalinity at the station A ranged from $50.18-50.28 \mathrm{mg} / \mathrm{l}$ and at $B$ it ranged from $50.18-50.30 \mathrm{mg} / 1$. The lowest values of alkalinity are recorded in the month of May at station A and in the month of June at station B; the highest values are observed in the month of January at both the stations. Rahul (2012) also reported decreased alkalinity during summer months. Similar observation was made during the present study also. Alkalinity can be defined as the sum of the negative ions reacting to neutralize hydrogen ions when acid is added to water. In natural waters alkalinity is mostly due to dissolved carbon dioxide $\left(\mathrm{CO}_{2}\right)$ or carbonate ions and it represents the main carbon source for assimila- -tion during photosynthesis.

Phosphate-phosphorous: The values of phosphorus at the station A ranged from $0.42-0.51 \mathrm{mg} / 1$ and at station $\mathrm{B}$ it ranged from $0.40-0.51 \mathrm{mg} / \mathrm{l}$. The lowest values of phosphorus were recorded in the month of July at both the stations and highest values in the month of June at both the stations. Increased concentration of phosphorus was observed during summer season and lower concentration during rainy season by Patil et al., (2013). A small amount of phosphorus is an essential nutrient for all aquatic plants and algae but in high levels, phosphorous can be considered a pollutant. Massive biological uptake of phosphorus occurs during the growth of phytoplankton and zooplankton.

Silicates: The values of silicates at the station A ranged from $0.32-0.54 \mathrm{mg} / \mathrm{l}$ and at $B$ ranged from $0.38-0.49 \mathrm{mg} / \mathrm{l}$. The silicates were reported lowest and highest in the month of November and June respectively at both the stations. Silica (silicon dioxide) is a compound of silicon and oxygen $\left(\mathrm{SiO}_{2}\right)$, a hard, glassy mineral substance which occurs in sand, quartz, sandstone and granite etc. Silicon has been considered as the most important limiting nutrient for growth of diatoms.

\section{References}

1. APHA, (1985). Standard methods for the examination of water and waste water. 16th ed. American Public Health Association. New York.

2. Banarjee, S.M. (1967). Water quality and soil condition of fishponds in states of India in relation to fish production. Indian Journal of Fisheries, 14 (1 \& 2): 115-144.

3. Odum, E.P. (1971). Fundamentals of Ecology. W.S. Saunders Co., Philandelphia, New York.

4. Mohan, M., Agrawal,V.P. and Sehgal, K. L. (2001). Pre-impoundment physico-chemical characteristics of river Gaula in Kumaon Himalaya. Proceeding of National Symposium on fish Health Management and Sustainable Aquaculture. 71-78. 
5. Patil, S. K., Patil, S.S. and Sathe, T.V. (2013). Limnological status of Khanapur fresh water reservoir from Ajara Tahsil, Kolhapur Distt. (M.S) India. International Journal of Science, Environment and Technology, 2(6): 1163-1174.

6. Verma, P.U., Chandawat, D. K. and H.A. Solanki (2011). Seasonal variation in physico-chemical and phytoplankton analysis of Kankaria Lake. Life Sciences leaflets, 19: 842-854. 49-63.

7. Rahul, A., Kushawaha, M.K.S., Mathur, R., Rahul, S. and Yadav, A. (2012). Assessment of freshwater quality of Angori reservoir, Distt. Datia, (M.P). Nature Environment and Pollution Technology, 11(4): 667-669.

8. Sharma, A. P. (2000). Manual on fishery limnology. College of Fisheries Science, GBPUAT, GBPUAT, Pantnagar. pp.115.
9. Thirupathaih, M., Ch. Sampata, Chintha Sammaiah (2012). Analysis of water quality using physico-chemical parameters in lower manair reservoir of Karimnagar District, Andhra Pradesh. International Journal of Environment Science, 3(1): 172-180.

10. Fakayode, S.O. (2005). Impact assessment of industrial effluent on water quality of the receiving Alora River in Ibadan, Nigeria. Ajeam-Ragee, 10:13.

11. Welch, P. S. (1952). Limnology, $2^{\text {nd }}$ edition, McGraw Hill Book Co. New York.

12. Wetzel, R. G. (1983). Limnology, W. B. Saunders Company, London. 